\title{
Total surgical correction of tetralogy of Fallot
}

\author{
Results in 45 consecutive cases
}

\author{
STANLEY JOHN, B. S. BHATI, P. SHAT A P A THY, \\ J. D. MCARTHUR, S. C. MUNSI, I. P. SUKUMAR, \\ and GEORGE CHERIAN
}

Departments of Cardiothoracic Surgery and Cardiology, Christian Medical College Hospital, Vellore, India

Total surgical correction of the tetralogy of Fallot remains a most challenging and difficult problem in cardiac surgery. The present study, like others, indicates that this lesion can be corrected, and excellent anatomical and haemodynamic results can be obtained with an acceptable mortality.

Results following total surgical correction in 45 consecutive patients are presented. The operative mortality was $13 \%$. The causes of death are analysed. Certain uncommon severe associated defects adversely influenced the outcome of the operation. The great majority of surviving patients are improved. Postoperative haemodynamic studies in eight patients revealed gratifying results.

In 1955 , after 10 years of palliative surgery using various shunt operations, Lillehei accomplished the first successful total surgical correction of the tetralogy of Fallot (Lillehei et al., 1955). The early mortality after the corrective operation was high, often in the range of $40 \%$; but today in most centres the operative mortality has been reduced to about $10 \%$ (Kirklin, Wallace, McGoon, and DuShane, 1965 ; Malm et al., 1966 ; Zerbini, 1969).

This is a review of 45 consecutive cases of Fallot's tetralogy which have been submitted to corrective surgery at the Christian Medical College Hospital, Vellore, India, between 1967 and 1971. This series constitutes the largest reported so far from this country.

The essential features of the complex anomaly presented here include a ventricular septal defect of a size approximating to the aortic orifice, and pulmonary stenosis of such severity that it, in combination with the ventricular septal defect, results in identical right and left ventricular pressures. There is, in addition, a varying degree of dextroposition of the aorta.

\section{MATERIAL AND METHODS}

Table I shows the 45 patients ranging in age from 4 to 26 years at operation. Their weights varied from $10 \mathrm{~kg}$ to $50 \mathrm{~kg}$. In this country we believe that, rather than age, a body weight of over $10 \mathrm{~kg}$ is a decisive factor in the decision regarding corrective surgery.

T A B L E I

AGE AT OPERATION

\begin{tabular}{c|c}
\hline Age Group (yr) & No. of Cases \\
\hline$<5$ & $3(7 \%)$ \\
$5-10$ & $11(24 \%)$ \\
$11-20$ & $23(51 \%)$ \\
$21-30$ & $8(18 \%)$ \\
\hline
\end{tabular}

The symptomatology before operation is illustrated in Table II. Of the 45 patients, 39 had central cyanosis of varying degree and six were acyanotic. Most of these cases were moderately symptomatic and belonged to functional class ii to iii, while six had severe cyanosis with anoxic spells (class iv, NYHA classification). Three of the 45 patients had episodes of congestive failure, in two of whom aortic incompetence complicated the lesion. Two patients were in refractory failure following shunt procedures. Preoperative cardiac catheterization in all documented the arterial saturation, varying from $42 \%$ to $95 \%$, and right ventricular hypertension at systemtic level, while angiocardiography showed the site and severity of right ventricular outflow tract obstruction in each case. Ciné aortography in two patients showed the presence of mild aortic incompetence. 
T A B L E I I

SYMPTOMS PRIOR TO SURGERY

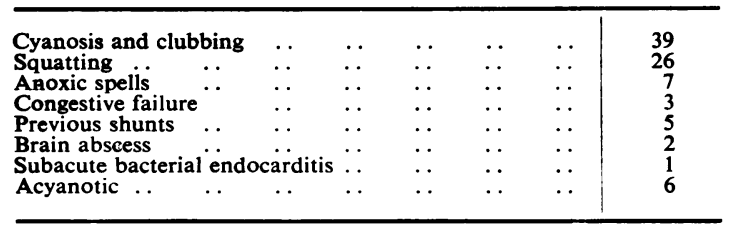

METHOD OF CORRECTIVE SURGERY Open intracardiac repair was carried out using mocerate total body hypothermia and extracorporeal circulation. A paracoronary right ventriculotomy incision was performed. Exposure was facilitated by intermittent cross-clamping of the aorta for 10 to 15 minutes with the temperature of the perfusate at $30^{\circ}$ to $32^{\circ} \mathrm{C}$. The site of obstruction to the right ventricular outflow tract was assessed in each case.

In the cyanotic group of 39 patients, 22 had combined infundibular and valvular obstruction while eight presented with a hypoplastic annulus in addition to the combined obstruction. Only one patient had valvar stenosis alone associated with a fibrotic annulus. Table III shows the type and incidence of obstruction. Resection of hypertrophied trabeculae carneae was accomplished through the ventriculotomy. Pulmonary valvotomy was done either through the right ventriculotomy or separately through an arteriotomy and, where necessary, deliberate excision of the pulmonary valve was carried out with or without the use of a pericardial gusset. A narrow fibrotic or hypoplastic annulus makes the use of an outflow gusset mandatory in most patients. A piece of peri- cardium was used for this. The ventricular defect was closed with a woven Teflon patch in all the patients as these defects were large and in many the margins were of soft red muscle. In five cases with a functioning systemic pulmonary anastomosis obliteration of the shunt was carried out before establishing bypass. One of these was a Waterston's shunt and the other four were Blalock's shunts. The average time of cardiopulmonary bypass was 1 hour 45 minutes with a range of 45 minutes to 2 hours 45 minutes. Postoperatively these patients needed assisted ventilation for 6 to 12 hours and careful monitoring of the electrocardiogram.

\section{RESULTS OF SURGERY}

Reoperation for evacuation of clots in the chest was performed in four patients. Six of the 45 patients died in the postoperative period, constituting an operative mortality of $13 \%$ (Figure).

In five of the 45 patients, an anastomotic procedure had been performed previously. There was no correlation between mortality and the presence or absence of a previous shunt. The mortality data are presented in Table IV. There was one instance of permanent heart block $(2 \%)$ in this small series of patients.

Certain uncommon severe associated defects (multiple ventricular septal defects, pronounced bronchopulmonary collaterals, aortic incompetence) did adversely influence the results of operation.

T A B L E I I I

SITE AND INCIDENCE OF RIGHT VENTRICULAR OUTFLOW TRACT OBSTRUCTION

\begin{tabular}{|c|c|c|c|c|c|}
\hline Group & No. & $\begin{array}{l}\text { Infundibular } \\
\text { Obstruction only }\end{array}$ & $\begin{array}{l}\text { Infundibular } \\
\text { and Valvular } \\
\text { Obstruction }\end{array}$ & $\begin{array}{l}\text { Infundibular, } \\
\text { Valvular, and Hypo- } \\
\text { plastic Annulus }\end{array}$ & $\begin{array}{l}\text { Va!vular only with } \\
\text { Fibrotic Annulus }\end{array}$ \\
\hline $\begin{array}{l}\text { Cyanotic } \\
\text { Acyanotic }\end{array}$ & $\begin{array}{r}39 \\
6\end{array}$ & $\begin{array}{l}8 \\
3\end{array}$ & $\begin{array}{r}22 \\
3\end{array}$ & $\begin{array}{l}8 \\
-\end{array}$ & $\begin{array}{l}1 \\
-\end{array}$ \\
\hline
\end{tabular}

T A B L E I V

MORTALITY DATA

1. Pulmonary oedema

2. Low cardiac output

3. Ventricular tachyarrhythmia and cardiac arrest

4. Severe bronchopneumonia

5. Acute renal failure

6. Haemorrhage from friable right ventricle
Two large interventricular septal defects closed with use of gusset outflow. Intractable pulmonary oedema postoperatively. Necropsy revealed an additional muscular interventricular septal defect

Early smooth postoperative course followed by severe bleeding from the tracheobronchial Early smooth postoperative course followed
tree, possibly the result of large collaterals

tree, possibly the result of large collaterals
Profoundly disabled boy, following an intrapericardial shunt three months prior to total correction in refractory congestive failure. Catheterization showed RV end-diastolic pressure $20 \mathrm{mmHg}$

Tetralogy of Fallot with continuous murmur. Total correction was carried out and she developed bronchopneumonia which was treated by positive pressure ventilation and antibiotics. Died 14 days after surgery

Congestive failure complicating anomaly. Went into acute renal failure, hyperkalaemia, and cardiac arrest

Aortic incompetence and congestive failure complicating tetralogy of Fallot. Following successful total correction developed severe bleeding from friable right ventricle which could not be controlled 


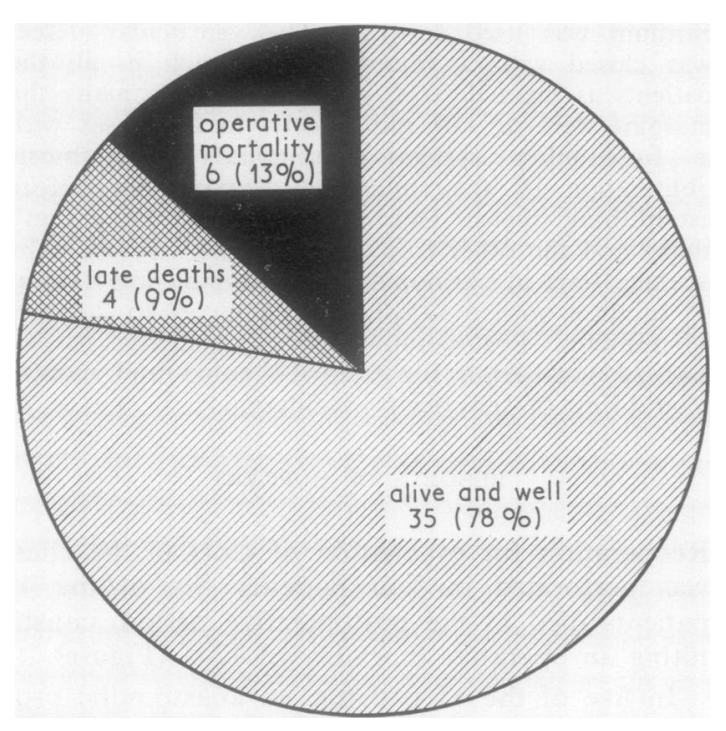

FIGURE. Results of surgery.

POSTOPERATIVE CLINICAL IMPROVEMENT There was marked clinical improvement in all the surviving patients except one (case 1 , Table V). He was seen 22 months after corrective surgery in congestive failure from a residual shunt and right ventricular outflow tract obstruction. He subsequently underwent a successful repair. The clinical

T A B L E V

RECATHETERIZATION DATA IN EIGHT CASES FOLLOWING TOTAL CORRECTION

\begin{tabular}{c|c|c|c}
\hline Case & $\begin{array}{c}\text { Residual } \\
\text { Shunt } \\
\text { (Qp/Qs) }\end{array}$ & $\begin{array}{c}\text { Residual Pulmonary } \\
\text { Stenosis (peak to } \\
\text { peak) } \\
\text { (mm gradient) }\end{array}$ & Improvement \\
\hline S.N. & $1 \cdot 75: 1$ & 80 & Nil \\
K.S. & Nil & Nil & Excellent \\
A.M. & Nil & Nil & Good \\
M.W. & Nil & 35 & Excellent \\
R.M. & $\mathrm{Nil}$ & 35 & Excellent \\
V.G. & $1.4: 1$ & 34 & Good \\
P.M. & Ni & 10 & Excellent \\
S.R. & Nil & 20 & Excellent \\
\hline
\end{tabular}

status of the survivors revealed an excellent result in $30(86 \%)$, good in four $(11 \%)$, and fair in one (3\%) at the time of follow-up, according to the grading of Baker and Hancock (1960). However, 8 of the 39 survivors underwent haemodynamic evaluation. The gratifying haemodynamic data in our patients have been reported previously (Munsi et al., 1970). The results are shown in Table V. There was an excellent result in five cases, good in two cases, and no improvement in one. However, this last patient underwent a successful reoperation.

Ten patients developed signs of pulmonary re- gurgitation postoperatively. It was significant in $\overrightarrow{\overrightarrow{\vec{b}^{2}}}$ three patients, all of whom had outflow gussets in serted as well as a pulmonary valvectomy. The other seven had only trivial regurgitation. Ans outflow tract gusset was used in 13 of the 39 sur viving patients.

There have been four late deaths in this series? One of these occurred in a severely incapacitated $\vec{\rho}$ poorly nourished adolescent boy. He developedcomplete heart block following surgery and is the్ only case of permanent heart block in this series? He died two-and-a-half months after surgery. Onex patient succumbed to a subacute bacterial endo $N$ carditis. One died eight months after surgicalcorrection from an unrelated gastroenteritis. Thes fourth patient died five months after corrective surgery from pneumococcal peritonitis. Necropsy revealed excellent closure of the interventricula $f_{5}$ septal defect with relief of outflow tract obstruc tion. There was no evidence of bacterial endo carditis and a diagnosis of pneumococcal peri tonitis was confirmed.

POSTOPERATIVE haEMODYNAMIC RESUlts Eight of the 39 survivors underwent haemodynamic evaluo ation 3 to 22 months postoperatively. The results are shown in Table V.

\section{DISCUSSION}

Three patients in this small series were 4 years of age and have done very well following corrective surgery, although a haemodynamic assessment has not yet been made. Recently, Burnell and co workers (1969) and Dobell, Charrette, and Chughta市 (1968) have reported excellent results in childre under 5 years of age. However, for infants ans small children less than 5 years of age an $\bar{\Phi}$. weighing less than $10 \mathrm{~kg}$, a shunt operation is preferable.

Of the 45 patients, 39 were cyanotic and 6 were acyanotic. There were no deaths in the acyanotic group. There appeared to be no striking correlas tion between polycythaemia and operative mor tality (Leachman, Hallman, and Cooley, 1965) However, the series is too small to draw any sign nificant conclusions about this effect (Table VI) N

\section{T A B L E V I}

RELATIONSHIP OF POLYCYTHAEMIA AND OPERATIVE
MORTALITY

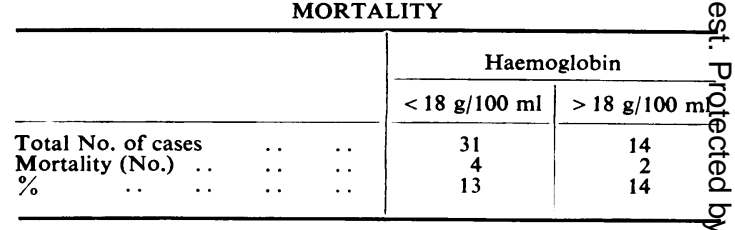


Only 2 of the 14 patients with a haemoglobin greater than $18.0 \mathrm{~g}$ died in the postoperative period.

Two patients were in refractory failure at the time of surgery, one following a Waterston's and the other after a Blalock shunt. The patient who had a Blalock shunt has had a satisfactory correction documented by recatheterization, demonstrating excellent haemodynamic data (case 4, Table V). The other patient died 16 hours after surgery from sudden cardiac arrest. His preoperative right ventricular end-diastolic pressure was $20 \mathrm{mmHg}$ (case 3, Table IV).

The operative mortality in this small series of 45 cases was $13 \%$, comparing favourably with some of the figures quoted by other groups. Gerbode et al. (1961) reported a mortality of $35 \%$, while Kirklin and his associates quoted an operative mortality of $15 \%$ lowered to $7 \%$, and Ikeda and Hirosawa (1968) from Tokyo University reported a $19 \%$ mortality.

The follow-up period has varied from four months to three and a half years. Functional capacity and exercise tolerance have been excellent in the 35 surviving patients, and arterial oxygen saturation and haemoglobin concentration have returned to normal in all cases.

Haemodynamic studies in eight cases revealed excellent results in five. The incidence of residual ventricular septal defect varied from 15 to $22 \%$ in previous published reports (Barnard and Schrire, 1966 ; Lillehei, Levy, Adams, and Anderson, 1964). In cases of doubt on oxygen analysis, we used an ascorbate dilution technique to rule out a shunt. Two out of eight cases showed evidence of a significant residual shunt. In spite of this evidence one of them is completely asymptomatic and leading a normal life.

Ten patients developed signs of pulmonary regurgitation in the postoperative period. Seven of these were considered trivial. The recent report of Bristow et al. (1970) that pulmonary regurgitation has been tolerated well up to 10 years postoperatively offers reassurance to the surgeon that where necessary an outflow gusset should be used.

\section{REFERENCES}

Baker, C., and Hancock, W. E. (1960). Deterioration after mitral valvotomy. Brit. Heart J., 22, 281.

Barnard, C. N., and Schrire, V. (1966). The surgical approach to tetralogy of Fallot. S. Afr. med. J., 40, 330.

Bristow, J. D., Kloster, F. E., Lees, M. H., Menashe, V. D., Griswold, H. E., and Starr, A. (1970). Serial cardiac catheterization and exercise haemodynamics after correction of tetralogy of Fallot. Circulation, 41, 1057.

Burnell, R. H., Woodson, R. D., Lees, M. H., Bristow, J. D., and Starr, A. (1969). Results of correction of tetralogy of Fallot in children under four years of age. J. thorac. cardiovasc. Surg., 57, 153.

Dobell, A. R. C., Charrette, E. P., and Chughtai, M. S. (1968). Correction of tetralogy of Fallot in the young child. J. thorac. cardiovasc. Surg., 55, 70.

Gerbode, F., Johnston, J. B., Sader, A. A., Kerth, W. J., and Osborn, J. J. (1961). Complete correction of tetralogy of Fallot. Arch. Surg., 82, 793.

Ikeda, M., and Hirosawa, K. (1968). Tetralogy of Fallot. Circulation, 38, Suppl. 5, 21.

Kirklin, J. W., Wallace, R. B., McGoon, D. C., and DuShane, J. W. (1965). Early and late results after intracardiac repair of tetralogy of Fallot. 5-year review of 337 patients. Ann. Surg., 162, 578.

Leachman, R. D., Hallman, G. L., and Cooley, D. A. (1965). Relationship between polycythemia and surgical mortality in patients undergoing total correction for tetralogy of Fallot. Circulation, 32, 65.

Lillehei, C. W., Cohen, M., Warden, H. E., Read, R. C., Aust, J. B., DeWall, R. A., and Varco, R. L. (1955). Direct vision intracardiac surgical correction of the tetralogy of Fallot, pentalogy of Fallot, and pulmonary atresia defects: report of first ten cases. Ann. Surg., 142, 418.

—, Levy, M. J., Adams, P., and Anderson, R. C. (1964). Corrective surgery for tetralogy of Fallot-long-term follow-up by postoperative recatheterization in sixtynine cases and certain surgical considerations. $J$. thorac. cardiovasc. Surg., 48, 556.

Malm, J. R., Blumenthal, S., Bowman, F. O., Ellis, K., Jameson, A. G., Jesse, M. J., and Yeoh, C. B. (1966). Factors that modify hemodynamic results in total correction of tetralogy of Fallot. J. thorac. cardiovasc. Surg., 52, 502.

Munsi, S. C., John, S., Joseph, T. M., Thomas, D. W., Bhati, B. S., Sukumar, L. P., Krishnaswami, S., McArthur, J. D., Thanikachalam, S., and Cherian, G. (1970). Results of total correction of tetralogy of Fallot in twenty-one cases. J. Ass. Phycns. India., 18, 585.

Zerbini, E. J. (1969). The surgical treatment of the complex of Fallot: late results. J. thorac. cardiovasc. Surg., 58, 158. 